\title{
Investigating the Relative Impacts of Distributive, Procedural and Interactional justice on Affective Organizational Commitment in the Egyptian Hotel Industry
}

\author{
Abuelhassan Elshazly Abuelhassan ${ }^{1} \quad$ Sultan Saber Alharbi $^{2} \quad$ Sawsan khreis $^{3}$ \\ ${ }^{1}$ Faculty of Hospitality and Tourism-Lincoln University College-Selangor, Malaysia, ${ }^{2}$ College of \\ Business-Umm Al-Qura University-Mecca, Saudi Arabia, ${ }^{3}$ Faculty of tourism and hotel management- \\ Yarmouk University-Jordan
}

\begin{abstract}
Drawing on the social exchange theory, this paper investigated the relationships between employees' affective organizational commitment (AOC) and their perceptions of the three forms of organizational justice (distributive justice [DJ], procedural justice [PJ] and interactional justice $[\mathrm{IJ}])$ in the hospitality context. Moreover, the current paper tested the relative impacts of these three forms on AOC. With a sample of 322 Luxor hotels' employees using confirmatory factor analysis and hierarchical regression analyses, the results revealed that the three forms of organizational justice have significantly positive effects on AOC. The results also found that the impact's powers of the three forms on AOC are significantly different indicating that PJ has the strongest effect on AOC while IJ has the lowest impact. These findings led to several theoretical and managerial implications and future research.
\end{abstract}

Keywords: Hospitality Industry, Affective Organizational Commitment, Distributive Justice, Procedural Justice, Interactional Justice, Luxor, Egypt.

\section{Introduction}

With growing local and global competition, individual work behaviors demand special attention (Abuelhassan and Elsayed, 2020; Alharthi, Khalifa, Abuelhassan, Isaac, and Al-Shibami, 2019; Alshehhi, Abuelhassan, and Bhaumik, 2019; Dhar, 2015). Given the importance of managing employee behavior in influencing the competitiveness of organizations (Alkhateri, Khalifa, and Abuelhassan, 2019; Alshehhi, Abuelhassan, and Nusari, 2019), employee organizational commitment has been considered a critical producer of the hospitality industry success (Alkathiri, Abuelhassan, and Khalifa, 2019), as well as, it plays a pivotal role in the hospitality industry's survival (Abuelhassan, Elsayed, and Soliman, 2017; Alkathiri, Khalifa, Abuelhassan, Isaac, and Alrajawi, 2019). A key reason for this is that the hospitality products and services are seen as intangible, (Widjaja, Khalifa, and Abuelhassan, 2020) it is difficult to separate them from their providers (Abdulla, Khalifa, Abuelhassan, and Ghosh, 2019; Abu-Elhassan, Elsayed, and Soliman, 2016; Abuelhassan et al., 2017; El-Hassan, Elsayed, and Soliman, 2015; Mohamud, Khalifa, Abuelhassan, and Kaliyamoorthy, 2017; Sudigdo, Khalifa, and Abuelhassan, 2019). Therefore, boosting employee organizational commitment neither only improves the service quality of the hotels (Dhar, 2015), but it will also result in the enhanced competitiveness of the hospitality business leading to preferable future organizational outcomes (Abdulla et al., 2020) (Patiar and Wang, 2016; Tsui, Lin, and Yu, 2013).

Particularly in the hospitality sector, evidence proposes a strong association between employee organizational commitment and performance (Khreis and Benghadbane, 2020; Khreis, Chapuis, and Shunnaq, 2020; Khreis et al., 2020; Patiar and Wang, 2016; Tsui et al., 2013). Also, a previous study found significant positive linkage between customer perceptions of service quality performance and employees' organizational commitment (Dhar, 2015). Thus, it is suggested that organizational commitment will positively impact word-of-mouth and generate hotels' customer satisfaction, loyalty and revisit intention (Gaan, 2011; Harrison-Walker, 2001; He, Li, and Keung Lai, 2011; Li and Petrick, 2010). In the employee context, it is found that organizational commitment is strongly linked to hotel employee satisfaction and turnover intention which are 
expected to develop highly competitive advantage, lower costs, revenue maximization and builds unique market share (Alkhateri, Abuelhassan, Khalifa, Nusari, and Ameen, 2018; Jang and Kandampully, 2018; Kang, Gatling, and Kim, 2015; Khreis, 2015).

However, three types of obligations were split from organizational commitment which are affective organizational commitment (AOC), continuance organizational commitment (COC), and normative organizational commitment (NOC) (Meyer and Allen, 1991), AOC has more significance as for improving job performance, absenteeism, turnover, and other desirable on-thejob behaviors (Breitsohl and Ruhle, 2013; Meyer, Stanley, Herscovitch, and Topolnytsky, 2002), thus, in the current research, AOC was adopted to represent organizational commitment.

In the organizational behavior field, research in organizational justice receives more attention from scholars and researchers (Alshamsi, Ameen, Nusari, Abuelhassan, and Bhumic, 2019; O'Connor and Crowley-Henry, 2019). Past studies revealed the importance of organizational justice on employee behavior (Moorman, Niehoff, and Organ, 1993) and attitudes (Choi, 2011; Viswesvaran and Ones, 2002). In the study of work-place justice, organizational justice is divided into three dimensions of justice namely distributive justice (DJ), procedural justice (PJ), and interactional justice (IJ) (Cohen-Charash and Spector, 2001a; Judge and Colquitt, 2004; Rupp and Cropanzano, 2002). DJ refers to employees' perceptions of the fairness of distributing the organizations' resources (e.g., salary, promotion, etc.) relied on employees' performance, education, and effort. While employees' perceptions of fairness and transparency of the processes in which the organizations' outcomes and rewards are made are conceptualized as PJ. On the other hand, the qualities of a work environment regarding respect and honesty are conceptualized as IJ.

Yet, in the Eastern and Western culture, it was found that various work outcomes and individual behaviors are correlated with organizational justice perceptions (e.g., Lam, Schaubroeck, and Aryee, 2002; Liao and Rupp, 2005), very few studies have been conducted on testing the impact of organizational justice's perceptions on individual behavior in the hospitality industry especially in the Egyptian hotels' context. Much prior work (e.g., Brockner, Chen, Mannix, Leung, and Skarlicki, 2000; Tyler, Boeckmann, Smith, and Huo, 1997) supposed that different societal and cultural settings had diverse effects on the associations between employees' work behaviors and employees' organizational justice perceptions and work results.

The employee cultural plays an important role in the relationship between employees' perceptions of AOC and the different forms of organizational justice. Cross-cultural comparisons' research (non-hospitality research) conducted in three countries (Australia, South Korea and China) by Jiang, Gollan, and Brooks (2017) to investigate the influence of distributive justice and procedural justice on affective commitment. However, the researchers united the participants' field (university employees) expecting that these employees tend to have similar organizational cultures (Jiang et al., 2017), it was found that the two forms have significant impacts on AOC in both China and South Korea, meanwhile, DJ has an insignificant impact on AOC in Australia. Yet, lack of knowledge is existed regarding the effects of the three organizational justice dimensions on organizational commitment in the hospitality context.

Furthermore, the influence of the dimensions of organizational justice has different strong impacts on organizational commitment. For instance, PJ most strongly predicted AOC than DJ (Lambert, Hogan, and Griffin, 2007), while in a previous study, it was found that there is no significant differences between PJ-AOC relationship and DJ-AOC relationship (Farmer, Beehr, and Love, 2003). while, several studies investigated and differentiated the different strong effects of DJ and PJ on AOC (Alexander and Ruderman, 1987; Bobocel and Mu, 2016; Moon, Hur, Ko, Kim, and Yoon, 2014; Safi and Arshi, 2016; Sani, 2013), a very few studies included 
interactional justice in the previous investigations (López-Cabarcos, Machado-Lopes-Sampaio-de Pinho, and Vázquez-Rodríguez, 2015a). Also, there exists a lack of research in testing and differentiating the strength of associations between the three dimensions of organizational and AOC.

The aim of this paper is to fill the existed research gap through (1) investigating the associations between hotels' employee AOC and their perceptions of organizational justice's dimensions, and (2) discovering which dimension of organizational justice is more predictive of AOC in the hotel industry in Luxor city, Egypt; across comparing the strength of relationships between AOC, and each form of organizational justice (PJ, DJ, and IJ). The current paper seeks to develop much more knowledge about organizational justice and organizational commitment in the hospitality industry. Based on the outcomes of the current study, further theoretical and practical implications will be derived, as well as some future research directions will be suggested.

\section{Literature review and hypotheses}

Social exchange theory (SET) which was described by (Blau, 1964: 91-92) as "the voluntary actions of individuals that are motivated by the returns they are expected to bring and typically do in fact bring from others" also was adopted to develop the current hypotheses. In the work settings, SET indicates that when employees expect some positive or negative future returns from employers, they tend to do a favor or revenge for them. SET is, thus, based on a long-term exchange of favors or revenge which produces reciprocations between employees and employers. Therefore, SET (Cook, Cheshire, Rice, and Nakagawa, 2013; Cropanzano and Mitchell, 2005) can deliver the conceptual support of research on employees' attitudes and behaviors because enhancing the favorable relationships between employers and their employees depend on what extent benefits or favors received by employees from their employers.

However, some scholars have reported that the different forms of organizational justice are critical for forming the individuals' affective commitment (Wu and Wang, 2008), very rare hospitality studies have conducted this kind of research. It was found that when organizations treat their employees fairly, the employees tend to develop and maintain favorable relationships with their organization as well as, they will show higher levels of job satisfaction, trust and commitment than they receive unfair treatment (Kim, 2009). In non-hospitality research, previous study focused on the impact of organization justice perceptions on employee attitudes and behaviors (Colquitt, Conlon, Wesson, Porter, and $\mathrm{Ng}$, 2001). This study revealed that organization justice has significant strong influences on both employees' attitudes (e.g., organization commitment, turnover intentions and job satisfaction) and behaviors (e.g., organizational citizenship behavior and absenteeism). Also, prior work had presented that when employees exhibit higher levels of organizational commitment, they perceive high levels of justice (Lowe and Vodanovich, 1995; Meyer et al., 2002; Moorman et al., 1993).

As it was highlighted by Meyer and Allen (1991), individuals with affective commitment desire to emotionally involve in, identify with and attach themselves to the employer. Drawing on SET, Ambrose and Schminke (2009), and Wayne, Shore, Bommer, and Tetrick (2002) individuals show a higher level of organizational commitment due to a higher level of justice they received from employer or organization, while they present a lower level of organizational commitment due to a lower level of justice they received. Accordingly, the current study hypotheses that:

H1: The three forms of organizational justice (DJ - PJ - IJ) have positive impacts on employee AOC.

Yet, much prior work had focused on studying the three types of organizational commitment (affective, continues and normative) through only the influence of distributive and procedural forms, while other researchers were unable to differentiate the different strong influences of these 
forms on AOC (Chai-Amonphaisal and Ussahawanitchakit, 2008; Klendauer and Deller, 2009). Exiting debates among scholars around which DJ or PJ has stronger impact on AOC, some studies had highlighted that DJ has a higher impact on AOC (Clay-Warner, Reynolds, and Roman, 2005; Farmer et al., 2003), adding to the complexity, other studies revealed that PJ has a stronger effect on AOC (Haque, Chowdhury, and Ali, 2010; Harvey and Haines Iii, 2005; LópezCabarcos, Machado-Lopes-Sampaio-de Pinho, and Vázquez-Rodríguez, 2015b). According to the researchers' knowledge, no studies have investigated the different strong effect of the three forms organizational justice on AOC especially in the hospitality context.

The current study suggests that PJ has a greater impact on employee AOC than both DJ and IJ because employees perceive DJ as the fairness of organizational outcomes; DJ is concerned with the 'ends' while they perceive procedural justice as the fairness of the process by which distributive organizational outcomes are allocated or organizational decisions are made; it is concerned with the 'means' (Greenberg, 1990; Hegtvedt and Markovsky, 1995; Lambert et al., 2007). According to Lind and Tyler (1988), the distribution of organizational outcomes does not indicate or justify the process/mean by which it is allocated. Also, it was found that however employees receive favorable or unfavorable organizational outcomes, their perceptions of PJ are very important for perceiving organizational justice as the reasons used to distribute organizational outcomes are justified and clear (Landy, Barnes-Farrell, and Cleveland, 1980). Additionally, Cropanzano, Bowen, and Gilliland (2007), and Jiang et al. (2017) suggested that PJ may be more associated with employees' beliefs and attitudes regarding the organization as a whole. Finally, Cohen-Charash and Spector (2001), and Lind and Tyler (1988) reported that PJ is likely to be the most important predictor of organizational justice perception. This argument leads the study to suppose that:

H2: PJ has a greater influence on AOC than DJ.

While the discussion regarding the more predictive of AOC between PJ and DJ was conducted (e.g., Farmer, Beehr, and Love, 2003) there is a lack of discussion comparing between IJ and PJ as well as between PJ and DJ as which one is more predictive of AOC. Whereas both PJ and DJ are focused on organization-employee relationship, on the other hand, IJ is concentrated on the interpersonal relationship between managers and their subordinates as another aspect of organizational justice such as employees' perception of politeness, respect, and honesty from the management (Bies and Moag., 1986; Cohen-Charash and Spector, 2001). In past literature, it was debated that interactional justice is more determined by the interpersonal behavior of managers and less determined by the organizational behavior, contrast, both PJ and DJ are more determined by the organizational behavior and less determined by the managers' behaviors. Thus, this discussion supports the present study to suggest that PJ and DJ are more predictive of organizational commitment than interactional justice (Cohen-Charash and Spector, 2001).

H3: PJ has a greater influence on AOC than IJ.

H4: DJ has a greater influence on AOC than IJ.

Methodology

\section{Procedure and samples}

Luxor hotels' employees were the target population of the present study. Thus, hotel general managers and human resource managers were contacted from 11 hotels (4 of four-star hotels and 7 of five-star hotels) reflecting the whole four and five-star hotels located in the Luxor city (Egyptian Hotel Association, 2020). The number of hotels that accepted the participation in the study is 8 hotels ( 3 of four-star hotels and 5 of five-star hotels).

The survey questionnaire was used to test the four hypotheses including four constructs - the three organizational justice forms and affective organizational commitment - in the suggested 
model. The survey is self-reported questionnaire which responded by hotels' employees from five and four-star hotels in Luxor, Egypt. The original questionnaires items were taken from English sources, and to follow Brislin, Lonner, and Thorndike's (1973) technique, two bilingual academics translated the questionnaire to Arabic and translated it back to English. The backtranslation process ensured that the translation was proper including a minor revision.

The questionnaire item measurement scales were adopted from previous studies which indicated the validity of these items. The questionnaire was divided into two parts. The first part included four constructs, namely, DJ, PJ, IJ and AOC. The three forms of organizational justice constructs were measured using a seven-point Likert scale ranging from one (strongly disagree) to seven (strongly agree), while AOC construct was measured using a five-point Likert scale ranging from one (strongly disagree) to five (strongly agree). The second part included demographic information such as gender, tenure, age and education.

The questionnaires were coded with an identification number, as well as each set of questionnaire has a cover letter indicating the aim of the research and mentioning that the employees' responses will be kept confidential. The first author submitted the employees' questionnaires were submitted to the HRMs for employees' survey distribution. The employees mailed the responded questionnaires to the first author's address using self-addressed pre-stamped envelopes. The questionnaires were randomly submitted to 400 employees which exceeded the perfect sample number (384) according to Sekaran and Bougie (2016), and 367 of them returned their questionnaires with a response rate of $91.75 \%$. After excluding the incomplete answers, the valid set for analysis is $322(80.5 \%)$. Of the 322 participants, most participants were male $(66.1 \%)$, almost $70 \%$ of participants were 31 years or older, only $4 \%$ had been recruited by the hotel for less than one year, and $56.3 \%$ has a bachelor's degree and higher.

\section{Measurements}

The items of the three forms of organizational justice were adopted from Colquitt (2001). In the current study, distributive justice's items are 4 items and the value for Cronbach's alpha is 0.855 . For procedural justice, 7 items were used and the value for Cronbach's alpha is 0.909. While interactional justice has 4 items with 0.808 Cronbach's alpha. Meanwhile, the effective organizational commitment 's items that have 6 items adopted from Meyer, Allen, and Smith (1993) have been utilized in Alkathiri et al. (2019), and Alkathiri, Khalifa, Abuelhassan, Isaac, and Alrajawi (2019) studies show 0.882 Cronbach's alpha in the present study.

\section{Control variables}

Following Jiang et al. (2017), and Mathieu and Zajac's (1990) recommendation, age, gender, educational level and organizational tenure were used as controlling variables because they may influence affective organizational commitment.

\section{Analysis}

The measurement theory needs Confirmatory factor analysis (CFA) as a method that is utilized to ensure or reject it (Alkutbi, Alrajawy, Nusari, Khalifa, and Abuelhassan, 2019; Alsaadi, Abuelhassan, Khalifa, Ameen, and Nusari, 2019; Hair, Black, Babin, and Anderson, 2010). With Maximum likelihood, the SPSS AMOS 25 software was employed to investigate CFA to ensure the construct validity and measure the fitness of the proposed model. Furthermore, the SPSS 25 was used to test the current hypotheses. For the hypotheses 2, 3, 4, the relative impacts of DJ, PJ and IJ on AOC were measured. This software also was used to calculate the amount of unique variance in affective organizational commitment explained by DJ, PJ and IJ. 


\section{Results}

Table 1: Demographic data of respondents

\begin{tabular}{|c|c|c|}
\hline Employee's profile $(n=322)$ & Frequency & Percentage $(\%)$ \\
\hline Gender & & \\
\hline Male & 213 & 66.1 \\
\hline Female & 109 & 33.9 \\
\hline Age & & \\
\hline less than 20 years & 18 & 5.6 \\
\hline $20-30$ years & 79 & 24.5 \\
\hline 31- 40 years & 117 & 36.4 \\
\hline $41-50$ years & 86 & 26.7 \\
\hline Above 50 years & 22 & 6.8 \\
\hline Education & & \\
\hline Senior School & 22 & 6.7 \\
\hline Diploma Graduation & 119 & 37.0 \\
\hline diploma & 176 & 54.7 \\
\hline M.sc or Ph.D & 5 & 1.6 \\
\hline Tenure & & \\
\hline less than one year & 13 & 4.0 \\
\hline $1-3$ years & 77 & 23.9 \\
\hline $4-6$ years & 120 & 37.3 \\
\hline $7-9$ years & 83 & 25.8 \\
\hline 10 years and above & 29 & 9.0 \\
\hline
\end{tabular}

\section{Construct validity}

The correlations, means, and standard deviations, among the constructs are showed in Table 2. The results present AOC to be significantly correlated with the three forms of organizational justice. Additionally, a variance inflation factors (VIF) test was performed. The VIF values are less than 5 ranging from 1.23 to 1.26 to indicate that the current study is free of multicollinearity issue. For construct validity, firstly, the CFA was carried out to assess the measurement model revealing a good fit $\left(\chi^{2} / \mathrm{df}=1.20 ; \mathrm{CFI}=0.99 ; \mathrm{GFI}=0.94 ; \mathrm{AGFI}=0.92 ; \mathrm{NFI}=0.94 ; \mathrm{NFI}=0.94\right.$; $\mathrm{IFI}=0.99$; TLI=0.999; RMSEA=0.03) see Fig 1. Secondly, the convergent validity was measured by the loading factor, the composite reliabilities (CR) and the average variance extracted (AVE). In Table 3, the factor loadings of all constructs' items were significant $(\mathrm{p}<0.001)$ ranging from 0.67 to 0.86 in the acceptable limits. Also, the CR values of all constructs are higher than 0.60 ranging from 0.81 (interactional justice) to 0.91 (procedural justice), as well as, the AVE values of them are greater than 0.50 ranging from 0.51 (interactional justice) to 0.60 (distributive justice), thus, the results of loading factors, CR, AVE' values ensure the convergent validity (Alharthi, Khalifa, Abuelhassan, Nusari, and Isaac, 2019; Anderson and Gerbing, 1988). Thirdly, in Table 2, the AVE value of each construct is greater than the squared correlation coefficient with other constructs highlighting that all the study constructs are distinct, thus, the discriminant validity is ensured (Alsaadi, Khalifa, Abuelhassan, Alrajawi, and Ibrhim, 2019; Alshehhi, Abuelhassan, and Bhaumik, 2019; Alshehhi, Abuelhassan, and Nusari, 2019; Fornell and Larcker, 1981).

As the respondents of the study survey were from one single source (employees), therefore, the challenge of common method bias (CMB) might exist. Harman's one factor test was utilized and the results indicated that the first factor explained a variance is $35.23 \%$ - less than 50\%, accordingly, this study is free of CMB issue (Podsakoff and Organ, 1986). 
International Journal of Heritage, Tourism and Hospitality Vol. (14), No. (1), June, 2020

Table 2: Descriptive analyses, correlations and discriminant validity

\begin{tabular}{|l|l|r|r|r|c|c|c|c|}
\hline \multirow{2}{*}{ Constructs } & \multirow{2}{*}{ Mean } & \multirow{2}{*}{ SD } & \multirow{2}{*}{ VIF } & \multicolumn{5}{|c|}{ Correlation } \\
\cline { 6 - 9 } & & & & $\mathbf{1}$ & $\mathbf{2}$ & $\mathbf{3}$ & $\mathbf{4}$ \\
\hline $\mathbf{1}$ & DJ & 4.32 & 1.47 & 1.26 & $\mathbf{0 . 5 9 5}$ & & & \\
\hline $\mathbf{2}$ & PJ & 4.45 & 1.31 & 1.23 & $0.419^{* *}$ & $\mathbf{0 . 5 9 2}$ & & \\
\hline $\mathbf{3}$ & IJ & 4.15 & 1.37 & 1.25 & $0.462^{* *}$ & $0.397 * *$ & $\mathbf{0 . 5 1 4}$ & \\
\hline $\mathbf{4}$ & AOC & 3.10 & 1.01 & ---- & $0.550^{* *}$ & $0.583^{* *}$ & $0.499 * *$ & $\mathbf{0 . 5 5 7}$ \\
\hline
\end{tabular}

Note: $* *=\mathrm{p}<0.001$; DJ= Distributive Justice; PJ= Procedural Justice; IJ= Interactional Justice; AOC=Affective Organizational Commitment, AVE's values are highlighted bold numbers in the correlation section

Table 3: Convergent Validity

\begin{tabular}{|c|c|c|c|c|}
\hline Paths & Scales & Loadings (t_value) & CR; AVE & $\mathbf{R 2}$ \\
\hline Distributive Justice & Reflective & & $0.86 ; 0.60$ & \\
\hline Distributive Justice $\rightarrow$ DJ1 & & $0.76 * * *$ & & 0.58 \\
\hline Distributive Justice $\rightarrow$ DJ2 & & $0.79 * * *(13.41)$ & & 0.63 \\
\hline Distributive Justice $\rightarrow$ DJ3 & & $0.77 * * *(13.55)$ & & 0.59 \\
\hline Distributive Justice $\rightarrow$ DJ4 & & $0.76 * * *(13.12)$ & & 0.58 \\
\hline Procedural Justice & Reflective & & $0.91 ; 0.59$ & \\
\hline Procedural Justice $\rightarrow$ PJ1 & & $0.73 * * *$ & & 0.54 \\
\hline Procedural Justice $\rightarrow$ PJ2 & & $0.83 * * *(14.52)$ & & 0.66 \\
\hline Procedural Justice $\rightarrow$ PJ3 & & $0.71 * * *(12.50)$ & & 0.50 \\
\hline Procedural Justice $\rightarrow$ PJ4 & & $0.86 * * *(15.20)$ & & 0.74 \\
\hline Procedural Justice $\rightarrow$ PJ5 & & $0.80 * * *(14.21)$ & & 0.64 \\
\hline Procedural Justice $\rightarrow$ PJ6 & & $0.74 * * *(13.21)$ & & 0.54 \\
\hline Procedural Justice $\rightarrow$ PJ7 & & $0.71 * * *(12.51)$ & & 0.50 \\
\hline Interactional Justice & Reflective & & $0.81 ; 0.51$ & \\
\hline Interactional Justice $\rightarrow$ IJ1 & & $0.71 * * *$ & & 0.50 \\
\hline Interactional Justice $\rightarrow$ IJ2 & & $0.70 * * *(10.76)$ & & 0.49 \\
\hline Interactional Justice $\rightarrow$ IJ3 & & $0.71 * * *(10.73)$ & & 0.50 \\
\hline Interactional Justice $\rightarrow$ IJ4 & & $0.75 * * *(11.31)$ & & 0.56 \\
\hline Affective Commitment & Reflective & & $0.88 ; 0.56$ & \\
\hline Affective Commitment $\rightarrow$ AC1 & & $0.74 * * *$ & & 0.54 \\
\hline Affective Commitment $\rightarrow$ AC2 & & $0.67 * * *(11.56)$ & & 0.45 \\
\hline Affective Commitment $\rightarrow$ AC3 & & $0.76 * * *(13.18)$ & & 0.58 \\
\hline Affective Commitment $\rightarrow$ AC4 & & $0.77 * * *(13.37)$ & & 0.59 \\
\hline Affective Commitment $\rightarrow$ AC5 & & $0.78 * * *(13.70)$ & & 0.61 \\
\hline Affective Commitment $\rightarrow$ AC6 & & $0.76^{* * *}(13.19)$ & & 0.57 \\
\hline
\end{tabular}

Note. $(*) \mathrm{p}<0.10 ;(* *) \mathrm{p}<0.05 ;(* * *) \mathrm{p}<0.00$; the composite reliability (CR); the average variance extracted $(A V E)$. Fit indices of the reflective measurement model: $\chi 2$ (d.f.) $=220.299(183) ; \mathrm{p}<0.05(\chi 2 /$ d.f. $=1.204)$; $C F I=$ $0.99 ; \mathrm{GFI}=0.94 ; \mathrm{AGFI}=0.92 ; \mathrm{IFI}=99 ; \mathrm{TLI}=0.99 ; \mathrm{NFI}=0.94 ; \mathrm{RMSEA}=0.03$;

\section{Hypotheses test}

In the current study, the R-square value (0.414) reveals that the three forms of organizational justice determine an adequate variance in AOC. The results in Table 4 indicate that the associations between AOC with DJ $(\beta=0.262, \mathrm{t}=5.347, \mathrm{p}<0.001), \mathrm{PJ}(\beta=0.354, \mathrm{t}=7.361, \mathrm{p}<$ $0.001)$ and $\mathrm{IJ}(\beta=0.196, \mathrm{t}=4.040, \mathrm{p}<0.001)$ are significantly positive, supporting $\mathrm{H} 1$. Also, in Table 4 , the effect of PJ $(\beta=0.35)$ on AOC is higher than DJ's effect $(\beta=0.26)$. Additionally, the corresponding amount of unique variance in AOC explained by PJ and DJ is $1.41 \%(\mathrm{p}<0.001)$ and $0.96 \%$ ( $\mathrm{p}<0.001$ ), supporting H2. In Hypothesis 3, PJ (compared with IJ) has a higher influence on AOC (0.35 vs. 0.20). Moreover, the unique variance values in AOC explained by IJ 
and PJ are $1.59 \%(\mathrm{p}<0.001)$ and $0.66 \%(\mathrm{p}<0.001)$, supporting H3. Finally, DJ (compared with $\mathrm{IJ})$ has a greater impact on AOC (0.26 vs. 0.20$)$. As well as, the corresponding amount of unique variance in AOC explained by DJ and IJ is $1.16 \%(\mathrm{p}<0.001)$ and $0.68 \%(\mathrm{p}<0.001)$, supporting $\mathrm{H} 4$. The values of standardized regression coefficient and the unique variance can be seen in Table 4.

Table 4: Results of hierarchical regression analysis for the hypothesized relationships.

\begin{tabular}{|c|c|c|}
\hline \multirow[t]{2}{*}{ Dependent Variable $\rightarrow$} & \multicolumn{2}{|c|}{ Affective organizational commitment } \\
\hline & Step 1 & Step 2 \\
\hline \multicolumn{3}{|l|}{ Control Variables } \\
\hline Gender & 0.047 & 0.019 \\
\hline Age & $0.131 *$ & 0.076 \\
\hline Education & -0.037 & -0.041 \\
\hline Tenure & 0.045 & 0.047 \\
\hline \multicolumn{3}{|l|}{ Independent Variable } \\
\hline DJ & & $0.262 * *$ \\
\hline PJ & & $0.354 * *$ \\
\hline IJ & & $0.196 * *$ \\
\hline F-value & $2.406^{*}$ & $31.748 * *$ \\
\hline$R^{2}$ & 0.029 & 0.414 \\
\hline Adjusted $R^{2}$ & 0.017 & 0.401 \\
\hline Change $R^{2}$ & & 0.385 \\
\hline \multicolumn{3}{|c|}{ Unique variance explained by DJ, PJ and IJ } \\
\hline & Unique variance & F-value \\
\hline PJ beyond DJ & 0.141 & $71.179 * *$ \\
\hline DJ beyond PJ & 0.096 & $48.591 * *$ \\
\hline PJ beyond IJ & 0.159 & $77.045^{* *}$ \\
\hline IJ beyond PJ & 0.066 & $32.046 * *$ \\
\hline DJ beyond PJ & 0.116 & $52.786^{* * *}$ \\
\hline PJ beyond DJ & 0.068 & $30.794 * *$ \\
\hline
\end{tabular}

Note: $* *=\mathrm{p}<0.001 ; \mathrm{DJ}=$ Distributive Justice; PJ= Procedural Justice; IJ= Interactional Justice

\section{Discussion and implications}

To achieve a competitive advantage, progress, and sustainability in the hotel industry, organizations have to pay more attention to employee AOC, as it was found that AOC has great impacts on employees' turnover intention (Alkhateri et al., 2018), service quality (Dhar, 2015) and performance (Alshehhi, Abuelhassan, and Bhaumik, 2019). Drawn on social exchange theory (SET), the current study contributes to the hospitality industry literature through investigating the effect of the three forms of organizational justice (DJ, PJ, and IJ) on AOC. The findings found that all these three forms have significant impacts on AOC in the Egyptian hospitality industry.

Existing debate around the significant impacts of the two forms of organizational justice (DJ and PJ) on AOC is influenced by different cultures (Jiang et al., 2017). Furthermore, in the Portugal Hotel Industry, it was found that both DJ and IJ have no significant effect on AOC (LópezCabarcos et al., 2015). The current findings agree with the previous studies that the three different forms of organizational justice have important impacts on AOC (Crow, Lee, and Joo, 2012; Müller and Djuatio, 2011; Swalhi, Zgoulli, and Hofaidhllaoui, 2017).

SET is the prevalent way of clarifying the association between employees and their organization (Cropanzano and Mitchell, 2005). In the work environment, SET is a type of reciprocal satisfaction exchange between an organization and its employees and the development of 
reciprocity under a popularized ethical criterion, which means that organizational fairness is seen as a substantial source of reciprocity (Greenberg, 1990). Accordingly, when organizations present their goodwill (justice) towards their individuals, like a good act in return, a positive obligation will be created from the individuals towards their organizations (Aryee, Budhwar, and Chen, 2002; Cropanzano and Mitchell, 2005).

One way to explicate these findings is to note that DJ or PJ are two types in which employees can judge the organizations' fairness through the fairness of organizations' outcomes distribution and the procedures by which these outcomes are made that ultimately influence the employees' AOC (Poon, 2012), as well as, these employees are considering the fairness of supervisors through fair interpersonal treatment as another facet of organizational justice because the supervisors/ managers represent as agent of the organization in implementing the organizational fairness and support (Li, 2014), hence, interactional justice can positively and significantly predict AOC (Farndale, Van Ruiten, Kelliher, and Hope-Hailey, 2011). Thus, favorable and fair treatment employees receive from their supervisors influences their affective commitment towards their organization.

Finally, very little research directly compares the distinct impacts of different forms of justice on AOC in the hospitality industry (e.g., López-Cabarcos et al., 2015). Another major contribution in the present study is to differentiate the different power impact of organizational justice's forms on AOC. The findings reveal that PJ has more power on AOC than DJ. However, DJ as the fair sharing of organizational resources is very important for building a good relationship between organizations and employees (Cropanzano et al., 2007), the feeling of equity does not rely only on organizational rewards' distributions but also and, far much significant, on the means and methods applied to make these distributions (Swalhi et al., 2017). The findings also find that and IJ has a lower impact on AOC than PJ and DJ. However, the significant effect of IJ on AOC in the current findings go along with several authors who mentioned that IJ is a more leaderemployee relationship than an organization-employee relationship. It was supposed that IJ - as interpersonal and informational justice such as politeness, honesty, respect, and a timely response and equity of given information (Colquitt, 2001) - evaluates the fairness of a manager / supervisor and both DJ and PJ measures the fairness of an organization (Folger and Cropanzano, 2001).

Fig 1: The CFA results

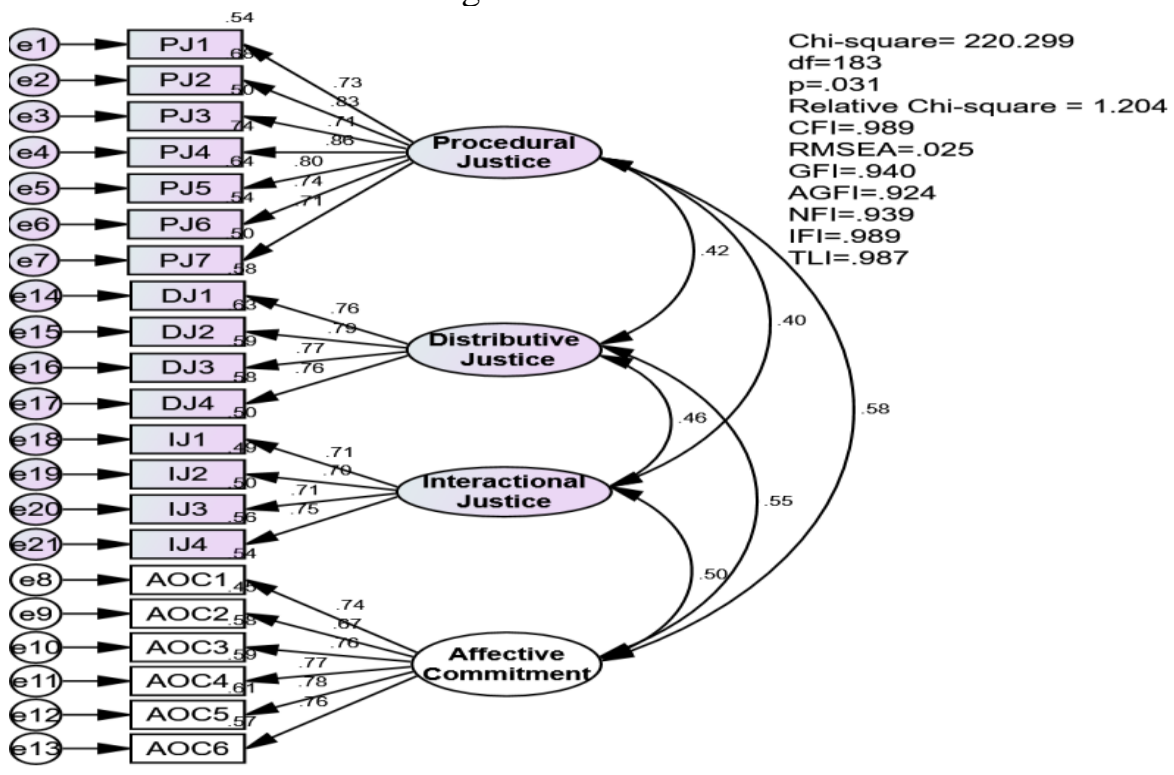


With the evidence of the Egyptian hospitality context, the results of this study validate, support and generalize the applicability of prior works highlighted the social exchange-based effects of justice in such a way that the different forms of organizational justice have a great impact on AOC. Thus, drawing on these results, hotels' top management is suggested to review their organizational justice practices and draft them in such a way that they positively influence the levels of employee AOC, to achieve favorable organizational outcomes such as increasing performance and competitive advantages, and declining employee turnover intention.

The hotels' top management and human resource directors (HRDs) should consider that PJ has the greatest effect on AOC among organizational justice's forms. Hotels' HRDs should review and ensure the processes by which hotels' training programs, promotion, performance appraisal, recruitment, and other human resources department's practices are achieved in a highly fair manner. Also, DJ should be highly appreciated by the top management as an important justice form influencing employees' commitment. Hotels' employees need to feel that the hotels' resources (e.g., rewards, compensations, and other benefits) are distributed fairly based on equitable criteria including employee effort or performance in order to reciprocate to their hotels with a high obligation.

Although IJ has the lowest effect among organizational justice's forms, still has a significant impact on employee commitment. The findings detect that to exchange emotional commitment from the employees to their hotels; these employees require receiving adequate respect and dignity from their supervisors/managers along with receiving enough information and rationale for the decisions made.

\section{Limitations and directions for future research}

Like much research on organizational behavior, the current study was limited by investigating the impact of organizational justice on affective commitment. For future research, the researchers suggest linking organizational behavior research (e.g., organizational justice) to market research (e.g., service quality) through the mediating role of affective commitment as a great predictor of service quality. The findings provided evidence from the Egyptian hospitality perspective that procedural justice has a higher effect on affective commitment than distributive and interactional justice; meanwhile, the latter has the lowest impact. For generalization, these results can be tested in another industry and geographical location.

\section{References}

Abdulla, S. A. M., Khalifa, G. S. A., Abuelhassan, A. E., and Ghosh, A. (2019). Antecedents of Dubai Revisit Intention: The Role of Destination Service Quality and Tourist Satisfaction. Restaurant Business, 118(10), 307-316.

Abdulla, S. A. M., Khalifa, G. S. A., Abuelhassan, A. E., Nordin, B. Bin, Ghosh, A., and Bhaumik, A. (2020). Advancement of Destination Service Quality Management Technology in Tourism industry. Journal of Critical Reviews, 7(11), 2317-2324.

Abu-Elhassan, A.-E. E., Elsayed, Y. N. M. K., and Soliman, D. M. (2016). The Influences of Modern Technologies on Generations' Job Satisfaction: Luxor Hotels Case Study. International Journal of Heritage, Tourism, and Hospitality, 7(2).

Abuelhassan, A. E., and Elsayed, Y. N. M. K. (2020). The Impact of Employee Green Training on Hotel Environmental Performance in the Egyptian Hotels. International Journal on Recent Trends in Business and Tourism, 4(1).

Abuelhassan, A. E., Elsayed, Y. N. M. K., and Soliman, D. M. (2017). Managers 'Perspective towards Employees' Generational Differences in Luxor Hotels. 1(January), 32-41.

Alexander, S., and Ruderman, M. (1987). The role of procedural and distributive justice in 
organizational behavior. Social Justice Research, 1(2), 177-198.

Alharthi, B. A. F. H., Khalifa, G. S. A., Abuelhassan, A. E., Isaac, O., and Al-Shibami, A. H. (2020). Re-Engineering University Performance: Antecedents and Mediating Variables. Journal of Engineering and Applied Sciences, 15(2), 714-729.

Alharthi, M. N. A. N., Khalifa, G. S. A., Abuelhassan, A. E., Nusari, M., and Isaac, O. (2019). Investigating the Impact of Leadership and Business Continuity Management on Organizational Crisis Performance. International Business Management, 13(7), 266-278.

Alkathiri, M. S., Abuelhassan, A. E., and Khalifa, G. S. A. (2019). Ethical Leadership, Affective Organizational Behaviour, and Leader-Member Exchange as Predictors for Employees Performance. Journal of Engineering and Applied Sciences, 14(9), 6998-7012.

Alkathiri, M. S., Khalifa, G. S. A., Abuelhassan, A. E., Isaac, O., and Alrajawi, I. (2019). Ethical Leadership as a Predictor for Employee's Performance: The Mediating Role of Affective Organizational Commitment. Journal of Engineering and Applied Sciences, 14(21), 78577869.

Alkhateri, A. S., Abuelhassan, A. E., Khalifa, G. S. A., Nusari, M., and Ameen, A. (2018). The Impact of perceived supervisor support on employees turnover intention: The Mediating role of job satisfaction and affective organizational commitment. International Business Management, 12(7), 477-492.

Alkhateri, A. S., Khalifa, G. S. A., and Abuelhassan, A. E. (2019). Antecedents for Job Satisfaction in Ras-Al-Khaimah, Schools: Evidence from UAE. Journal of Engineering and Applied Sciences, 14(15), 5097-5110.

Alkutbi, S., Alrajawy, I., Nusari, M., Khalifa, G. S. A., and Abuelhassan, A. E. (2019). Impact of Ease of Use and Usefulness on the Driver Intention to Continue Using Car Navigation Systems in the United Arab Emirates. International Journal of Management and Human Science, 3(1), 1-9.

Alsaadi, T. A. R. M., Abuelhassan, A. E., Khalifa, G. S. A., Ameen, A., and Nusari, M. (2019). Empowering Leadership Predictors for Employees Creativity. International Business Management, 13(3), 119-129.

Alsaadi, T. A. R. M., Khalifa, G. S. A., Abuelhassan, A. E., Alrajawi, O. I., and Ibrhim. (2019). Empowering Leadership as a Predictor for Employees Creativity: The Mediating Role of Intrinsic Motivation. International Business Management, 13(8), 318-330.

Alshamsi, O., Ameen, A., Nusari, M., Abuelhassan, A. E., and Bhumic, A. (2019). Towards a Better Understanding of Relationship between Dubai Smart Government Characteristics and Organizational Performance. International Journal of Recent Technology and Engineering, 14(17), 21-23.

Alshehhi, S., Abuelhassan, A. E., and Bhaumik, A. (2019). The Influence of Transformational Leadership on Employees ${ }^{\text {ee }}$ Performances Through Organizational Commitment Within Public Sectors in United Arab Emirates (Uae). International Journal of Innovative Technology and Exploring Engineering, 8(8s2), 527-540.

Alshehhi, S., Abuelhassan, A. E., and Nusari, M. (2019). Effect of Transformational Leadership on Employees ${ }^{e e}$ Performances Through Job Satisfaction Within Public Sectors in Uae. International Journal of Innovative Technology and Exploring Engineering, 8(8s2), 588597.

Ambrose, M. L., and Schminke, M. (2009). The role of overall justice judgments in organizational justice research: A test of mediation. Journal of Applied Psychology, 94(2), 491.

Anderson, J. C., and Gerbing, D. W. (1988). Structural equation modeling in practice: A review 
and recommended two-step approach. Psychological Bulletin, 103(3), 411.

Aryee, S., Budhwar, P. S., and Chen, Z. X. (2002). Trust as a mediator of the relationship between organizational justice and work outcomes: Test of a social exchange model. Journal of Organizational Behavior: The International Journal of Industrial, Occupational and Organizational Psychology and Behavior, 23(3), 267-285.

Bies, R. J., and Moag., J. S. (1986). Interactional communication criteria of fairness. Research in Organizational Behavior, 9, 289-319.

Blau, P. M. (1964). Social exchange theory. Retrieved September, 3(2007), 62.

Bobocel, D. R., and Mu, F. (2016). Organizational justice and employee commitment: A review of contemporary research. In Handbook of Employee Commitment. Edward Elgar Publishing.

Breitsohl, H., and Ruhle, S. (2013). Residual affective commitment to organizations: Concept, causes and consequences. Human Resource Management Review, 23(2), 161-173.

Brislin, R. W., Lonner, W. J., and Thorndike, R. M. (1973). Cross-cultural research methods: Comparative studies in behavioral science. New York, NY: A Wiley-Intersection Publication.

Brockner, J., Chen, Y.-R., Mannix, E. A., Leung, K., and Skarlicki, D. P. (2000). Culture and procedural fairness: When the effects of what you do depend on how you do it. Administrative Science Quarterly, 45(1), 138-159.

Çelik, S., Dedeoğlu, B. B., and Inanir, A. (2015). Relationship between ethical leadership, organizational commitment and job satisfaction at hotel organizations. Ege Akademik Baklş Dergisi, 15(1), 53-64.

Chai-Amonphaisal, K., and Ussahawanitchakit, P. (2008). Roles of human resource practices and organizational justice in affective commitment and job performance of accountants in Thai firms. Review of Business Research, 8(2), 47-58.

Choi, S. (2011). Organizational justice and employee work attitudes: The federal case. The American Review of Public Administration, 41(2), 185-204.

Clay-Warner, J., Reynolds, J., and Roman, P. (2005). Organizational justice and job satisfaction: A test of three competing models. Social Justice Research, 18(4), 391-409.

Cohen-Charash, Y., and Spector, P. E. (2001a). The role of justice in organizations: A metaanalysis. Organizational Behavior and Human Decision Processes, 86(2), 278-321.

Cohen-Charash, Y., and Spector, P. E. (2001b). The role of justice in organizations: A metaanalysis. Organizational Behavior and Human Decision Processes, 86(2), 278-321.

Colquitt, J. A. (2001). On the dimensionality of organizational justice: A construct validation of a measure. Journal of Applied Psychology, 86(3), 386.

Colquitt, J. A., Conlon, D. E., Wesson, M. J., Porter, C. O. L. H., and Ng, K. Y. (2001). Justice at the millennium: a meta-analytic review of 25 years of organizational justice research. Journal of Applied Psychology, 86(3), 425.

Cook, K. S., Cheshire, C., Rice, E. R. W., and Nakagawa, S. (2013). Social exchange theory. In Handbook of social psychology (pp. 61-88). Springer.

Cropanzano, R., Bowen, D. E., and Gilliland, S. W. (2007). The management of organizational justice. Academy of Management Perspectives, 21(4), 34-48.

Cropanzano, R., and Mitchell, M. S. (2005). Social exchange theory: An interdisciplinary review. Journal of Management, 31(6), 874-900.

Crow, M. S., Lee, C.-B., and Joo, J.-J. (2012). Organizational justice and organizational commitment among South Korean police officers: An investigation of job satisfaction as a mediator. Policing: An International Journal of Police Strategies and Management, 35(2), 402-423.

Dhar, R. L. (2015). Service quality and the training of employees: The mediating role of 
organizational commitment. Tourism Management, 46, 419-430.

Egyptian Hotel Association. (2020). Hotels. Retrieved August 12, 2020, from http://www.egyptianhotels.org/Home/Hotels

El-Hassan, A. E. A., Elsayed, Y., and Soliman, D. (2015). Job Satisfaction and Generational Differences: Luxor Hotel Employees Case Study. Egyptian Journal of Tourism Studies Vol, 14(1).

Farmer, S. J., Beehr, T. A., and Love, K. G. (2003a). Becoming an undercover police officer: A note on fairness perceptions, behavior, and attitudes. Journal of Organizational Behavior: The International Journal of Industrial, Occupational and Organizational Psychology and Behavior, 24(4), 373-387.

Farmer, S. J., Beehr, T. A., and Love, K. G. (2003b). Becoming an undercover police officer: A note on fairness perceptions, behavior, and attitudes. Journal of Organizational Behavior: The International Journal of Industrial, Occupational and Organizational Psychology and Behavior, 24(4).

Farndale, E., Van Ruiten, J., Kelliher, C., and Hope-Hailey, V. (2011). The influence of perceived employee voice on organizational commitment: An exchange perspective. Human Resource Management, 50(1), 113-129.

Folger, R., and Cropanzano, R. (2001). Fairness theory: Justice as accountability. Advances in Organizational Justice, 1, 1-55.

Fornell, C., and Larcker, D. F. (1981). Structural equation models with unobservable variables and measurement error: Algebra and statistics. SAGE Publications Sage CA: Los Angeles, CA.

Gaan, N. (2011). A Revisit on Impact of Job Attitudes on Employee Turnover: An Empirical Study in Indian IT Industry. Vilakshan: The XIMB Journal of Management, 8(2).

Greenberg, J. (1990). Organizational justice: Yesterday, today, and tomorrow. Journal of Management, 16(2), 399-432.

Hair, J. F., Black, W. C., Babin, B. J., and Anderson, R. E. (2010). Multivariate data analysis: Global edition. Pearson Higher Education Upper Saddle River, NJ.

Haque, M. M., Chowdhury, M. A. A., and Ali, M. (2010). Effect of organizational justice over affective commitment and the role of marital status. 2010 IEEE 17Th International Conference on Industrial Engineering and Engineering Management, 1805-1814. IEEE.

Harrison-Walker, L. J. (2001). The measurement of word-of-mouth communication and an investigation of service quality and customer commitment as potential antecedents. Journal of Service Research, 4(1), 60-75.

Harvey, S., and Haines Iii, V. Y. (2005). Employer treatment of employees during a community crisis: The role of procedural and distributive justice. Journal of Business and Psychology, 20(1), 53-68.

He, Y., Li, W., and Keung Lai, K. (2011). Service climate, employee commitment and customer satisfaction: evidence from the hospitality industry in China. International Journal of Contemporary Hospitality Management, 23(5), 592-607.

Hegtvedt, K. A., and Markovsky, B. N. (1995). Justice and injustice.

Jang, J., and Kandampully, J. (2018). Reducing employee turnover intention through servant leadership in the restaurant context: A mediation study of affective organizational commitment. International Journal of Hospitality and Tourism Administration, 19(2), 125141.

Jiang, Z., Gollan, P. J., and Brooks, G. (2017). Relationships between organizational justice, organizational trust and organizational commitment: a cross-cultural study of China, South 
Korea and Australia. The International Journal of Human Resource Management, 28(7), 973-1004.

Judge, T. A., and Colquitt, J. A. (2004). Organizational justice and stress: the mediating role of work-family conflict. Journal of Applied Psychology, 89(3), 395.

Kang, H. J., Gatling, A., and Kim, J. (2015). The impact of supervisory support on organizational commitment, career satisfaction, and turnover intention for hospitality frontline employees. Journal of Human Resources in Hospitality and Tourism, 14(1), 68-89.

Khreis, S., and Benghadbane, F. (2020). Best Practices for Tour Guides in the Northern Region of Jordan:"Land of Olive Oil and Indigenous Food." In Cases on Tour Guide Practices for Alternative Tourism (pp. 96-118). IGI Global.

Khreis, S., Chapuis, J. M., and Shunnaq, M. (2020). Best Practices for Tour Guides at Christian and Islamic Religious Sites: A Case Study of Jordan. In Cases on Tour Guide Practices for Alternative Tourism (pp. 154-180). IGI Global.

Kim, H.-S. (2009). Examining the role of informational justice in the wake of downsizing from an organizational relationship management perspective. Journal of Business Ethics, 88(2), 297.

Klendauer, R., and Deller, J. (2009). Organizational justice and managerial commitment in corporate mergers. Journal of Managerial Psychology, 24(1), 29-45.

Lam, S. S. K., Schaubroeck, J., and Aryee, S. (2002). Relationship between organizational justice and employee work outcomes: a cross-national study. Journal of Organizational Behavior, 23(1), 1-18.

Lambert, E. G., Hogan, N. L., and Griffin, M. L. (2007). The impact of distributive and procedural justice on correctional staff job stress, job satisfaction, and organizational commitment. Journal of Criminal Justice, 35(6), 644-656.

Landy, F. J., Barnes-Farrell, J. L., and Cleveland, J. N. (1980). Perceived fairness and accuracy of performance evaluation: A follow-up. Journal of Applied Psychology, 65(3), 355.

Li, X., and Petrick, J. F. (2010). Revisiting the commitment-loyalty distinction in a cruising context. Journal of Leisure Research, 42(1), 67-90.

Li, Y. (2014). Building affective commitment to organization among Chinese university teachers: the roles of organizational justice and job burnout. Educational Assessment, Evaluation and Accountability, 26(2), 135-152.

Liao, H., and Rupp, D. E. (2005). The impact of justice climate and justice orientation on work outcomes: a cross-level multifoci framework. Journal of Applied Psychology, 90(2), 242.

Lind, E. A., and Tyler, T. R. (1988a). The social psychology of procedural justice. Springer Science and Business Media.

Lind, E. A., and Tyler, T. R. (1988b). The social psychology of procedural justice. Springer Science and Business Media.

López-Cabarcos, M. Á., Machado-Lopes-Sampaio-de Pinho, A. I., and Vázquez-Rodríguez, P. (2015a). Organizational justice and personal initiative, mediating role of affective commitment. Journal of Service Theory and Practice, 25(6), 854-876.

López-Cabarcos, M. Á., Machado-Lopes-Sampaio-de Pinho, A. I., and Vázquez-Rodríguez, P. (2015b). The influence of organizational justice and job satisfaction on organizational commitment in Portugal's hotel industry. Cornell Hospitality Quarterly, 56(3), 258-272.

Lowe, R. H., and Vodanovich, S. J. (1995). A field study of distributive and procedural justice as predictors of satisfaction and organizational commitment. Journal of Business and Psychology, 10(1), 99-114.

Mathieu, J. E., and Zajac, D. M. (1990). A review and meta-analysis of the antecedents, 
correlates, and consequences of organizational commitment. Psychological Bulletin, 108(2), 171.

Meyer, J. P., and Allen, N. J. (1991). A three-component conceptualization of organizational commitment. Human Resource Management Review, 1(1), 61-89.

Meyer, J. P., Allen, N. J., and Smith, C. A. (1993). Commitment to organizations and occupations: Extension and test of a three-component conceptualization. Journal of Applied Psychology, 78(4), 538.

Meyer, J. P., Stanley, D. J., Herscovitch, L., and Topolnytsky, L. (2002). Affective, continuance, and normative commitment to the organization: A meta-analysis of antecedents, correlates, and consequences. Journal of Vocational Behavior, 61(1), 20-52.

Mohamed, M. S., Khalifa, G. S. A., Nusari, M., Ameen, A., Al-Shibami, A. H., and Abuelhassan, A. E. (2018). Effect of Organizational Excellence and Employee Performance on Organizational Productivity Within Healthcare Sector in the UAE. Journal of Engineering and Applied Sciences, 13(15), 6199-6210.

Mohamud, S. S., Khalifa, G. S. A., Abuelhassan, A. E., and Kaliyamoorthy, S. (2017). INVESTIGATING THE ANTECEDENTS OF COFFEE SHOP CUSTOMERS'BEHAVIORAL INTENTIONS IN KUALA LUMPUR. International Journal on Recent Trends in Business and Tourism, 1(4), 1-14.

Moon, T.-W., Hur, W.-M., Ko, S.-H., Kim, J.-W., and Yoon, S.-W. (2014). Bridging corporate social responsibility and compassion at work: Relations to organizational justice and affective organizational commitment. Career Development International, 19(1), 49-72.

Moorman, R. H., Niehoff, B. P., and Organ, D. W. (1993). Treating employees fairly and organizational citizenship behavior: Sorting the effects of job satisfaction, organizational commitment, and procedural justice. Employee Responsibilities and Rights Journal, 6(3), 209-225.

Müller, J., and Djuatio, E. (2011). Les relations entre la justice organisationnelle, l'employabilité, la satisfaction et l'engagement organisationnel des salariés. Revue de Gestion Des

Ressources Humaines, (4), 46-62.

O'Connor, E. P., and Crowley-Henry, M. (2019). Exploring the relationship between exclusive talent management, perceived organizational justice and employee engagement: bridging the literature. Journal of Business Ethics, 156(4), 903-917.

Patiar, A., and Wang, Y. (2016). The effects of transformational leadership and organizational commitment on hotel departmental performance. International Journal of Contemporary Hospitality Management, 28(3), 586-608.

Podsakoff, P. M., and Organ, D. W. (1986). Self-reports in organizational research: Problems and prospects. Journal of Management, 12(4), 531-544.

Poon, J. M. L. (2012). Distributive Justice, Procedural Justice, Affective Commitment, and Turnover Intention: A Mediation-Moderation Framework 1. Journal of Applied Social Psychology, 42(6), 1505-1532.

Rupp, D. E., and Cropanzano, R. (2002). The mediating effects of social exchange relationships in predicting workplace outcomes from multifoci organizational justice. Organizational Behavior and Human Decision Processes, 89(1), 925-946.

Safi, M.-H., and Arshi, S. (2016). The Relationship between Perceived Organizational Justice and Organizational Commitment with Job Satisfaction in Employees of Northern Tehran Health Care Center. Community Health (Salāmat-i Ijtimā̄i), 2(3), 172-181.

Sani, A. (2013). Role of procedural justice, organizational commitment and job satisfaction on job performance: The mediating effects of organizational citizenship behavior. International 
Journal of Business and Management, 8(15), 57.

Sekaran, U., and Bougie, R. (2016). Research methods for business: A skill building approach. John Wiley and Sons.

Sudigdo, A., Khalifa, G. S. A., and Abuelhassan, A. E. (2019). DRIVING ISLAMIC ATTRIBUTES, DESTINATION SECURITY GUARANTEE and DESTINATION IMAGE TO PREDICT TOURISTS' DECISION TO VISIT JAKARTA. International Journal on Recent Trends in Business and Tourism, 3(1), 59-65.

Swalhi, A., Zgoulli, S., and Hofaidhllaoui, M. (2017). The influence of organizational justice on job performance: The mediating effect of affective commitment. Journal of Management Development, 36(4), 542-559.

Tsui, P.-L., Lin, Y.-S., and Yu, T.-H. (2013). The influence of psychological contract and organizational commitment on hospitality employee performance. Social Behavior and Personality: An International Journal, 41(3), 443-452.

Tyler, T. R., Boeckmann, R. J., Smith, H. J., and Huo, Y. J. (1997). Social justice in a diverse society Boulder. CO: Westview.

Viswesvaran, C., and Ones, D. S. (2002). Examining the construct of organizational justice: A meta-analytic evaluation of relations with work attitudes and behaviors. Journal of Business Ethics, 38(3), 193-203.

Wayne, S. J., Shore, L. M., Bommer, W. H., and Tetrick, L. E. (2002). The role of fair treatment and rewards in perceptions of organizational support and leader-member exchange. Journal of Applied Psychology, 87(3), 590.

Widjaja, Y. I., Khalifa, G. S. A., and Abuelhassan, A. E. (2020). The Effect of Islamic Attributes and Destination Affective Image on the Reputation of the Halal Tourism Destination of Jakarta. Journal of Environmental Management and Tourism, 11(2), 299-313.

$\mathrm{Wu}, \mathrm{X}$., and Wang, C. (2008). The impact of organizational justice on employees' pay satisfaction, work attitudes and performance in Chinese hotels. Journal of Human Resources in Hospitality and Tourism, 7(2), 181-195. 